\title{
Charlemagne - Emperor and Reformer. On the 1200th Death Anniversary
}

\begin{abstract}
The purpose of this paper is to present the role of Charlemagne (768-814), King of the Franks and Emperor of the Romans (from 800) in the process of recovering the school organisation that was considerably weakened in the period from the 5 th to the 7 th century as well as the participation of the ruler in the reforms of education, science and the school system, referred to as the Carolingian Renaissance. In his reforms of the legal system, the monetary system, administration and education, Charles consistently implemented the political program announced in the Act of 789 .

The emperor's actions reveal a clearly utilitarian goal. The command of Latin and the introduction of readable writing enabled the clergy to better understand the words of the Holy Scripture and, in turn, increased the general level of religious education among believers. The numerous scriptoria across the empire contributed to the ongoing work on defining the uniform text of all the books. The rebirth of Latin was driven by the works of the late Roman grammarians, Donatus and Priscian, and many works by ancient authors were also copied in scriptoria.
\end{abstract}

Keywords: Charlemagne, carolingian renaissance, history of education

2014 marked the 1200th anniversary of the death of Charlemagne (768-814), King of the Franks and Emperor of the Romans (from 800) and it was a good occasion to look back at his achievements in education and legislation related to educational matters. When the emperor was dying at dawn on 28 January 814, his country was the most powerful political organism in Europe and that was to a large extent his own achievement ${ }^{1}$.

There is a massive amount of sources related to the creator of the Carolingian Empire and it is not a purpose of this paper to review these sources, but it must be noted that works on Charlemagne are regularly published by eminent specialists who also explore the his-

\footnotetext{
${ }^{1}$ See: WIES, E.W., Karol Wielki. Cesarz i święty, Warsaw 1996, passim.
} 
tory of education ${ }^{2}$. The purpose of this paper is to present the role of the emperor in the process of recovering the school organisation that was considerably weakened in the period from the 5 th to the 7 th century as well as the participation of the ruler in the reforms of education, science and the school system, referred to as the Carolingian Renaissance.

Charles became an independent ruler at the age of 26. After Pepin's death on 24 September 768, his two sons, Charles (in Noyon) and Carloman (in Soissons), were both anointed and crowned on 29 October 768. Carloman died on 4 December 771 in Samoussy and Charles became the sole ruler. It must be noted that the Frankish king knew how to gather around himself people devoted to the project of reforms, though he did not refrain from brutal methods in the process ${ }^{3}$. In the sphere of politics, Charles was also a brutal and ruthless ruler. He did not flinch from mass deportations and exterminations during the Saxon Wars and he shaped the legal and political system of the empire with strong and unrelenting consistency. As a result, his empire covered a large area from today's Belgium and the Netherlands to the Elbe in the east, the Danube in the north and a significant part of today's Italy in the south.

In his reforms of the legal system, the monetary system, administration and education, Charles consistently implemented the political program announced in the Act of 789 . A person who had a major influence on the contents of this key Carolingian document was Alcuin of York, an actual author of the project of reforms covering the Church and education in the Frankish Kingdom ${ }^{4}$. However, it should be noted that the inspiration for educational reforms included in this document was probably the insight into the situation in the north of Italy after the conquest of the Lombard Kingdom in 772. The educational traditions of the antiquity were still very much alive there and the court in Pavia had a school for laymen that was run by Paulinus during the reign of King Desiderius. In 774, the court of King Charles saw the arrival of Peter of Pisa, formerly associated with the Lombard court, who was to become one of the authors of the reform.

In Admonitio generalis (798), Charlemagne ordered that there should be a school at every monastery. He also defined the curriculum (Article 72) that included Psalms, writing, singing, arithmetic and grammar ${ }^{5}$. This initiative was justified, since there hardly ex-

2 The particularly noteworthy publications include: The Gentle Voices of Teachers. Aspects of Learning in the Carolingian Age, ed. R.E. SULLIVAN, Columbus 1995; CLAUSSEN, M.A., The Reform of the Frankish Church. Chrodegang of Metz and the Regula canonicarum in the Eight Century, Cambridge 2004; MCKITTERICK, R., Charlemagne. The Formation of a European Identity, Cambridge 2008.

${ }^{3}$ HALPEN, L., Charlemagne and the Carolingian Empire. Europe in the Middle Ages Selected Studies, vol. 3, ed. R. VAUGHAN, Amsterdam-New York-Oxford 1977, p. 38ff.

${ }^{4}$ EWIG, E., Das Zeitalter Karls des Großen (768-814), [in:] Handbuch der Kirchengeschichte, ed. H. JEDIN, vol. 3: Die mittelalterliche Kirche. Erster Halbband: Vom kirchlichen Frühmittelalter zur gregorianischen Reform, ed. F. KEMPF et al., Freiburg-Basel-Wien 1985, p. 83ff.

5 KAROLI, Admonitio Generalis, [in:] Monumenta Germaniae Historica, [hereinafter referred to as MGH] Leges, sectio II, Capitularia regum Francorum, vol. 1, ed. A. BORETIUS, Hannoverae 1883, quoted in: $M G H$, p. 121. See also: RICHÉ, P., Chrześcijaństwo na karolińskim Zachodzie (połowa VIII - koniec IX wieku), [in:] Religia, kultura, polityka, ed. J.M. MEYER et al., vol. 4: Biskupi, mnisi i cesarze. 610-1054, ed. G. DAGRON, P. RICHÉ, A. VAUCHEZ, Warsaw 1999, vol. 4, p. 596. 
isted any educational system in the country. At the assembly in Frankfurt, where also a council was taking place at the time, King of the Franks recommended that bishops should diligently perform their educational duties ("On the necessity of cultivating sciences"). In line with the statute, a would-be priest should command the skills of reading, ecclesiastical chant, writing etc. The council encouraged parents to send their children to schools and entrusted priests with the task of providing good education ${ }^{6}$. This document addressed the disastrous situation of education which could severely limit the activity of the Church and did not bode well for the future of the imperial administration. The king made it clear that all teachers should be perfectly familiar with the Roman tradition ${ }^{7}$.

In 794-796, Charles addressed a general letter on humanities to Baugulf, the abbot at the Fulda monastery. This letter is known as Epistola de litteris colendis ${ }^{8}$. The ruler commanded that more effort should be taken to improve the knowledge of Latin among the clergy.

In 802 , the emperor introduced exams obligatory for all clergymen and in 803 he ordered his officials that they should allow ordaining of priests only if the candidates had passed the required exams.

In 817, the council in Aachen issued Institutio sanctimonialum, based on the guidelines of St Jerome. The curriculum of monastery schools was to include religious, intellectual and practical education. Latin was a mandatory subject, but, contrary to Jerome's view, Greek and Hebrew were not required. Literary education comprised selected books from the Bible, works by the Church Fathers and lives of saints ${ }^{9}$. It is a good example of interconnections between the particular law and monastic rules.

Taking into account the above legal acts, theoretically it was Charlemagne's Admonitio generalis of 789 that had the greatest impact on the school curriculum ${ }^{10}$. Though issued by the royal chancellery, this document was based on the principles of the canon law and the Roman law and its parts that bear special interest to the author of this paper were addressed to the clergy. Admonitio was, as already mentioned, the first document by Charles regarding the organisation of the education system. In a document issued at the general assembly of the Franks on 23 March, King Charles ordered that the school curriculum should include Psalms, nota (writing of the musical score), computus (rules of the Church calen-

${ }^{6}$ KAROLI, Admonitio generalis, [in:] MGH, Capitularia..., op. cit., vol. 1, p. 235.

7 Ibidem, cap. 4, p. 234.

${ }^{8}$ KAROLI, Epistola de litteris colendis, [in:] MGH, Capitularia..., op. cit., vol. 1, no. 29, p. 78ff. According to Giles Brown, the text dates back to 780-790. BROWN G., Introduction: the Carolingian Renaissance, [in:] Carolingian culture: emulation and innovation, ed. R. MCKITTERICK, Cambridge 1994, p. 20.

9 STĘPNIEWSKA, A., "Wychowanie rodzinne dziewcząt w pedagogice św. Hieronima”, Vox Patrum, 1985, 8-9, p. 174; RATAJCZAK, K., "Poglądy Ojców Kościoła na wychowanie i edukację kobiet”, Biuletyn Historii Wychowania, 2002, 15-16, p. 15-23.

${ }_{10}$ There are numerous publications regarding this act. See: FAŁKOWSKI, W., Cesarstwo karolińskie, [in:] Narodziny średniowiecznej Europy, ed. H. SAMSONOWICZ, Warsaw 1999, p. $252 \mathrm{ff}$. 
dar) and grammar ${ }^{11}$. A similar program of education was presented by Charlemagne in his letter to Baugulf, the abbot of the Fulda monastery, regarding the necessity of cultivating sciences and development of cathedral and monastery schools, dating back to $794-800^{12}$. It must be emphasised that the king ordered that the school curriculum should be implemented at each bishopric and each monastery. Furthermore, educational facilities had the obligation to collect diligently corrected books ${ }^{13}$. One must not forget that the background for Epistola de litteris colendis was also the training of missionaries for the needs of the growing empire, so the development of education was to serve the interests of the state as well ${ }^{14}$. Both acts laid down the foundations for the minimal requirements that the secular clergy and monastic orders in the territory of the empire had to meet ${ }^{15}$. In 794, Charles instructed the bishops regarding the duty of providing thorough education to their subjects. Each priest had to be fluent in reading, writing, singing, stenography, computus and meditation. The king encouraged parents to send their children to schools and asked the clergy to ensure good education of their students. At the Council of Rispach (798), Arn, the bishop of Salzburg, followed the royal instructions and ordered that proper schools should be opened in his diocese, and the individual resolutions converged with the contents of "On the necessity of cultivating sciences ${ }^{16}$."

In addition to legislation, Charles undertook many other actions to improve the level of education in his country. For this purpose, he brought teachers from abroad, e.g. from Ireland ${ }^{17}$. As noted by one the emperor's biographers: he commanded one of them, Clemens, to settle in Gaul and entrusted to his care boys from the lowest and highest families, ordering that, if need be, they should be provided with food, and giving them a proper place to study. Another teacher was sent to Italy to a monastery of St Augustine near Ticinum, so that everyone willing to study could gather and learn from him ${ }^{18}$. In order to

${ }^{11}$ KAROLI, Admonitio generalis, ed. A. BORETIUS, [in:] MGH; Capitularia regum Francorum, ed. G.H. PERTZ, vol. 1, Berlin 1835 (reprint 1991), no. 22, p. 59ff. See: FAŁKOWSKI, W., Admonitio generalis Karola Wielkiego - zapowiedź tworzenia państwa idealnego, [in:] Ludzie. Kościół. Wierzenia. Studia z dziejów kultury i społeczeństwa Europy Środkowej (średniowiecze - wczesna epoka nowożytna), ed. W. IWAŃCZAK, S. K. KUCZYŃSKI, Warsaw 2001, p. 419-428; RICHÉ, P., Chrześcijaństwo na karolińskim Zachodzie (połowa VIII-koniec IX wieku), [in:] Historia chrześcijaństwa. Religia, kultura, polityka, ed. J. M. MEYER et al., vol. 4: Biskupi, mnisi i cesarze. 610-1054, ed. G. DAGRON, P. RICHÉ, A. VAUCHEZ, Warsaw 1999, p. $596 \mathrm{ff}$.

12 KAROLI, Epistola de litteris colendis, op. cit., p. 121; See also: WALLACH, L., "Charlemagne's De litteris colendis and Alcuin. A diplomatic - historical study", Speculum, 1951, 26, no. 2, p. 288-305; (here also the full edition of the text) and FAŁKOWSKI, W., Admonitio generalis Karola Wielkiego..., op. cit., p. 420.

${ }^{13}$ KAROLI, Epistola de litteris colendis, op. cit., no. 29, p. 60.

${ }^{14}$ EWIG, E., Das Zeitalter Karls des Großen, op. cit., p. 100.

15 KIJEWSKA, A., Edukacja karolińska, p. 170.

${ }^{16}$ MGH, Capitularia..., op. cit., vol. 1, no. 116, cap. 4, p. 234.

17 NOTKER BALBULUS, De Carolo Magno libri IV, [in:] Bibliotheca rerum germanicarum, vol. 4, Berlin 1867, p. 631-632.

18 NOTKER BALBUS, translated in: Europa w średniowieczu. Wybór źródel do historii powszechnej średniowiecza, ed. G.P. BĄBIAK, J. KALISZUK and E. POTKOWSKI, Pułtusk 1996, p. 21. 
provide the best teachers, he also travelled to Italy in $787^{19}$. Aachen functioned as the official capital of the empire from 794 and there Charles brought Agobard and Theodulf from the south of Gaul, Paul the Deacon from Italy, Peter of Pisa, Paulinus of Aquileia as well as Angilbert and Einhard from Franconia. These people were the academic elite of their time. They and their disciples were destined to create the foundations of the reform that led, in line with the king's intention, to the renaissance of the Roman empire with its effective administration and education system that was to reinforce the integrity of the state. In 776, Paulius, a poet and a teacher from Lombardy, joined the king's milieu. In 770, Peter of Pisa, a grammarian, was present at the court, and in 781 Charles had a meeting with Alcuin in Parma. Another influential person in the period of the Carolingian reforms was Paul the Deacon, a poet and a historian, who stayed at the royal court in 781786. Theodulf, a Visigoth, came from Spain, but the true leader of the reform was Alcuin, the head of the palace school in 793-798. The ruler granted church dignities to the scholars who made their contribution to the school and the academy: Paul the Deacon became the abbot at Monte Cassino, Paulinus was the patriarch of Aquileia from 787, Fardulf took over the abbey of Saint-Denis in 793 and Theodulf became the bishop of Orleans in 798.

A crucial problem that was partly resolved by Charlemagne related to the flow of information in his large country, and specifically, the operation of the state administration. Due to the lack of any uniform ductus of writing within the empire, the written communication was extremely difficult. For this reason, the king, though he was himself virtually illiterate, put special emphasis on the reform of writing ${ }^{20}$. The result was the emergence of a clear style of writing used for documents and books that is still known today, with some minor changes, as the popular Times New Roman font. The reform of writing significantly increased the production of books and the diversity of content. An important side effect was the renaissance of the antique writing culture which was noticed particularly in the context of the grammar studies aimed at improving the correct use of Latin. During the reign of Charlemagne, books were instruments of culture and study, and the considerable growth in the number of available books was possible due to the rapid development of monastic scriptoria where top-quality miniatures were also made ${ }^{21}$. Books were also produced at the royal/imperial chancellery, the court academy and the palace school. Numerous books were also collected in Aachen, later to be included in the royal libraries.

The sufficiently extensive production of books was necessary to establish the numerous schools across the country. Teams of scribes were to be organized at major schools (in Rheims, Orleans, Tours, Fulda, Saint Riquier, Corbie, Fleury), and particularly at the palace school in Aachen. More than seven thousand manuscripts from the Carolingian era have survived and many of them were produced for the needs of the schools. They includ-

19 Adémar de Chabannes noted in his chronicle: et dominus rex Karolus iterum a Roma artis grammaticae et computatoriae magistros secum addiuxit in Franciam et ubique studium litterarum expandere iussit, [in:] MGH, Scriptores, vol. 4, p. 118.

${ }^{20}$ GIEYSZTOR, A., "Problem karolińskiej reformy pisma”, Archeologia, 1952-1953, 5, p. 155-177.

${ }^{21}$ See: SKUBISZEWSKI, P., Malarstwo europejskie $w$ średniowieczu, vol. 1: Malarstwo karolińskie i przedromańskie, Warszawa 1973. 
ed texts by Virgil, Sedulius, Cicero, Plato, Horace, Pliny, Suetonius, Augustine, Jerome, Origen and John Chrysostom ${ }^{22}$.

The palace school referred to above was undoubtedly one of the most interesting initiatives of Charlemagne. It was run by Alcuin of York (735-804) who made it into one of the best educational facilities in a short time ${ }^{23}$. It is worth mentioning that Alcuin was also Charlemagne's personal advisor. In one of his letters, he underlines that one of the fundamental duties of a ruler is to teach and instruct his people and, among others, to adopt laws $^{24}$. It was a peculiar return to one of the prerogatives of Roman emperors related to the title of Pontifex maximus, i.e. a guardian of cult and tradition. Upon the king's request, Alcuin composed the educational curriculum for the entire empire. It included liberal arts in line with the canon dating back to the times of antiquity. Alcuin's program of grammar classes comprised the works of Virgil, Statius, Juvenal, Terence and Lucian ${ }^{25}$. Rhetoric focused on the skill of literary writing which was practices with the use of Quintilian's Institutes of Oratory and Cicero's De oratore. The models for speech skills included the Catiline Orations and Livy. Dialectic, i.e. the skill of logical reasoning, was taught on the basis of philosophical treatises by Boethius and Porphyry.

As regards education at the level of quadrivium, Alcuin tends to minimize the former area of its disciplines. Geometry and arithmetic covered, in fact, the speculation on the mystical value of numbers and exercises related to the manipulation of Roman numerals. Astronomy consisted in the methods to calculate the date of Easter and, in some extent, star divination. Music was generally a practical science, but it included a theory of relations that created the harmony of the cosmos, the human body and sounds ${ }^{26}$.

Alcuin was not a creative mind, but he had extensive experience and knowledge acquired at the school in York. He also acted as the advisor and teacher of King Charles and his children. He contributed to didactics by writing handbooks of grammar, rhetoric and dialectic. Alcuin believed that true wisdom led to salvation.

Upon the emperor's request, the curriculum of the Aachen palace school was extended with physica (medicine) in 805 . The graduates included the future collaborators of Emperor Louis the Pious (814-840) whose ambition was to continue the reforms initiat-

${ }^{22}$ MCKITTERICK, R., Script and book production, [in:] Carolingian Culture: emulation and innovation, ed. R. MCKITTERICK, Cambridge 1994, p. 221-247.

${ }^{23}$ For a review of source see: RATAJCZAK, K., Szkoła pałacowa, [in:] Encyklopedia pedagogiki XXI w, vol. 6, Warsaw 2007, p. 369-370. Key sources: DUCKETT, E., Alcuin. Friend of Charlemagne, New York 1951. Some researchers express doubts about the major role of Alcuin - see: BROWN, G., Introduction: the Carolingian Renaissance, [in:] Carolingian Culture: emulation and innovation,op. cit., p. 32.

${ }^{24}$ ALCUINI, Epistolae, [in:] MGH, IV: Karolinum aevum, vol. 2, no. 177, Berolini 1895, p. 293. See: FAŁKOWSKI, W., "Uwagi o ideowym programie rządów Karola Wielkiego", Roczniki Historyczne, 2004, 70, p. $65-79$.

${ }^{25}$ LAW, V., The Study of grammar, [in:] Carolingian Culture: emulation and innovation, p. 88-110.

${ }^{26}$ For differences between the classic division and content of liberal arts and Alcuin's canon, see: RATAJCZAK, K., Sztuki wyzwolone, [in:] Encyklopedia pedagogiczna XXI wieku, vol. 6, Warszawa 2007 , p. 342-343; MIŚKIEWICZ, M., Zarys kultury i archeologii Europy w okresie wczesnego średniowiecza, Warsaw 2002, p. 186. 
ed by Charlemagne, Unfortunately, after Louis' death decentralist tendencies won the day and the empire was divided under the Treaty of Verdun in 843.

The Aachen academy was formed by a small group of educated friends of the king of the Franks and each of them adopted a name after a great literary figure of the past, e.g. Homer or Pindar ${ }^{27}$. The pseudonym of Charles was King David and it clearly indicated that despite the seemingly "democratic" character of the academic meetings it was always the king who had the last word. The Aachen school was a very lively institution and teachers often rotated. Typically, teachers moved to other places and established schools, thereby extending the range of the Carolingian reform. School graduates often appeared at the imperial court, e.g. Angilbert or Einhard. The centres of the Carolingian Renaissance were also the scriptoria where many graduates of the new schools worked. The group of scholars connected with Charlemagne included: Naso, Ethelwulf, Hibernicus Exul, Sedulius Scotus, Angilbert, Gottschalk, Ermeneric, Wandalbert, Agius, Thegan of Trier, Nithard, Smaragdus, Ermoldus Nigellus, Agobard of Lyon, Paschalis Radbertus, Ratram, Hincmar of Rheims, Milo of St. Amand.

The Carolingian Renaissance unified the law, developed sciences and romanized the liturgy, thereby contributing to the expansion and growth of Christianity ${ }^{28}$. Charlemagne's initiatives were imitated by other rulers, especially by Alfred the Great (849-899), King of Wessex, who brought scholars from other countries and established a school at his court. The significance of the Carolingian Renaissance is still widely argued. Extremely divergent opinions can be found in the related sources. Some researchers grant this period hardly any importance in the history of European culture. In his publication of 1959, Marian Henryk Sarejski concludes that the Carolingian Renaissance lacks innovation and humanist tendencies ${ }^{29}$. He also adds further on: the Carolingian Renaissance had some impact on a small elite of clergymen and its purposes pertained mainly to the sphere of the Church and religion. It merely re-adapted the models of the past ${ }^{30}$. For Jerzy Kłoczowski, this argument was the starting point for the praise of the authors of the Carolingian educational reforms who based their work on Latin as the language of the liturgy and the Church as well as of law and culture in general. Hence came the impressive educational effort that went top-down and resulted in establishing parish schools. Kłoczowski believes that the Carolingian minuscule was the key achievement of the period - that very same style of clear writing we have been using until today in all post-Latin Europe ${ }^{31}$. This view coincides with the conclusion of Giles Brown who points out that the Carolingian Renaissance introduced order into the grammatical rules of Latin, increased the number of

${ }^{27}$ HENDERSON, G., Wczesne średniowiecze, Warsaw 1984, p. 112.

${ }^{28}$ See: MCKITTERICK, R., Królestwa Karolingów. Władza-konflikty-kultura, 751-987, Warsaw 2011, p. 167-196; p. 230-259. Including a list of sources.

29 SEREJSKI, M.H., Karol Wielki na tle swoich czasów, Warsaw 1959, p. 254.

30 Ibidem, p. 267.

${ }^{31}$ KŁOCZOWSKI, J., U podstaw chrześcijańskiej kultury: chrześcijaństwo zachodnie wczesnego średniowiecza, [in:] Narodziny średniowiecznej Europy, ed. H. SAMSONOWICZ, Warsaw 1999, p. 96. 
schools, and thereby the number of literate people, for whom the monastic scriptoria produced more than seven thousand books. ${ }^{32}$ The Carolingian minuscule became the favourite style of writing for the Renaissance humanists and its key significance for the assessment of the entire period of the Carolingian Renaissance is also underlined by Ian Wood who says that one cannot limit its impact solely to the narrow milieu of the court, the rebirth of Latin and the interest in the Bible studies. ${ }^{33}$

The emperor's actions reveal a clearly utilitarian goal. The command of Latin and the introduction of readable writing enabled the clergy to better understand the words of the Holy Scripture and, in turn, increased the general level of religious education among believers. The numerous scriptoria across the empire contributed to the ongoing work on defining the uniform text of all the books. The rebirth of Latin was driven by the works of the late Roman grammarians, Donatus and Priscian, and many works by ancient authors were also copied in scriptoria.

Originally, the establishment of schools for future monks and sons of aristocratic families was of secondary importance, but with time it acquired a truly mythical significance: in the 19th century Charlemagne became a patron of students (including secular schools). The students' festival was held on 28 January. ${ }^{34}$ It is beyond doubt that the emperor's intention was to build a system of education that would be available for the society at large.

The historiographical controversies around the Carolingian Renaissance pertain to its narrow scope and elitist character ${ }^{35}$. This is undoubtedly true, but the final result of the large-scale reforms did not depend solely on Charlemagne. One must admit that after his death the reform was continued by Emperor Louis the Pious (814-828) who, however, lacked some of the exceptional qualities of his father. It is trued that during his reign 25 major abbeys were reformed with a special emphasis put on the intellectual development of the monks (Benedict of Aniane was the key figure). Einhard ran and further developed the palace school where the Frankish aristocracy gained their education. It was also a thriving period for numerous cathedral and monastery schools, e.g. in Lyon, Padua, Bobbio, SaintDenis, Corbie, Ferrieres, Fulda, and Reichenau. Charlemagne's son issued his Admonitio ad omnes regni ordines (825) that was very similar in its spirit to the famous Admonitio of his predecessor, while in the north of Italy (Lombardy) educational reforms were implemented by Lothar, but the political conditions had become much less conducive to the intellectual renaissance. After the Treaty of Verdun (843), it was only the cathedral school in Laon that remained an important centre of education and book production ${ }^{36}$.

32 BROWN, G., Introduction: the Carolingian Renaissance, p. 34. See also: MCKITTERICK, R., Script and book production, [in:] Carolingian Culture: emulation and innovation, ed. R. MCKITTERICK, Cambridge 1994.

${ }^{33}$ WOOD, I., Kultura, [in:] Zarys historii Europy, vol. 2: Wczesne średniowiecze od 400 do 1000 r., ed. R. MCKITTERICK, Warsaw 2003, p. 216; quote on p. 225.

${ }^{34}$ LE GOFF, J., Karol Wielki: między historia a mitem, [in:] Świat średniowiecza. Studia ofiarowane Profesorowi Henrykowi Samsonowiczowi, ed. A. BARTOSZEWICZ et al., Warsaw 2010, p. 623.

35 See: BROWN, G., Introduction: the Carolingian Renaissance, p. 1-51.

${ }^{36}$ CONTRENI, J. J., The Cathedral School of Laon from 850 to 930. Its Manuscripts and Masters, Münich 1978. 


\section{Bibliography}

\section{Sources}

ALCUINI, Epistolae, in: Monumenta Germaniae Historica, Epistolae, IV: Karolinum aevum, vol. II, No. 177, Berolini 1895.

KAROLI Admonitio generalis, ed. A. BORETIUS in: Monumenta Germaniae Historica, Leges, sectio II, Capitularia regum Francorum, vol. I, ed. G.H. PERTZ, Hannoverae 1883, No. 22 [reprint Berlin 1991].

KAROLI, Epistola de litteris colendis, in: MGH, Capitularia regum Francorum, vol. I, No. 29.

NOTKER BALBULUS, De Carolo Magno libri IV, in: Bibliotheca rerum germanicarum, vol. IV, Berlin 1867.

\section{Literature}

BROWN G., Introduction: the Carolingian Renaissance, in: Carolingian culture: emulation and innovation, ed. R. McKitterick, Cambridge 1994.

CLAUSSEN M.A., The Reform of the Frankish Church. Chrodegang of Metz and the Regula canonicarum in the Eight Century, Cambridge 2004.

CONTRENI J.J., The Cathedral School of Laon from 850 to 930. Its Manuscripts and Masters, Münich 1978.

DUCKETT E., Alcuin. Friend of Charlemagne, New York 1951.

EWIG E., Das Zeitalter Karls des Großen (768-814), in: Handbuch der Kirchengeschichte, hrsg. v. H. Jedin, vol. 3: Die mittelalterliche Kirche, Erster Halbband: Vom kirchlichen Frühmittelalter zur gregorianischen Reform, von F. KEMPF et al., Freiburg-Basel-Wien 1985.

FAŁKOWSKI W., Admonitio generalis Karola Wielkiego - zapowiedź tworzenia państwa idealnego, in: Ludzie. Kościót. Wierzenia. Studia z dziejów kultury i społeczeństwa Europy Środkowej (średniowiecze - wczesna epoka nowożytna), ed. W. IWAŃCZAK, S.K. KUCZYŃSKI, Warszawa 2001, pp. 419-428.

FAŁKOWSKI W., Cesarstwo karolińskie, in: Narodziny średniowiecznej Europy, ed. H. SAMSONOWICZ, Warszawa 1999.

FAŁKOWSKI W., Uwagi o ideowym programie rządów Karola Wielkiego, "Roczniki Historyczne" 70 (2004), pp. 65-79.

GIEYSZTOR A., Problem karolińskiej reformy pisma, "Archeologia” 5 (1952-1953), pp. 155177.

HALPEN L., Charlemagne and the Carolingian Empire. Europe in the Middle Ages Selected Studies, vol. 3, ed. R. VAUGHAN, Amsterdam-New York-Oxford 1977.

HENDERSON G., Wczesne średniowiecze, Warszawa 1984.

KŁOCZOWSKI J., U podstaw chrześcijańskiej kultury: chrześcijaństwo zachodnie wczesnego średniowiecza, in: Narodziny średniowiecznej Europy, ed. H. SAMSONOWICZ, Warszawa 1999.

LAW V., The Study of grammar, in: Carolingian Culture: emulation and innovation, ed. R. MCKITTERICK, Cambridge 1994, pp. 88-110.

LE GOFF J., Karol Wielki: między historia a mitem, in: Świat średniowiecza. Studia ofiarowane Profesorowi Henrykowi Samsonowiczowi, ed. A. BARTOSZEWICZ et al., Warszawa 2010.

McKITTERICK R., Charlemagne. The Formation of a European Idenity, Cambridge 2008.

McKITTERICK R., Królestwa Karolingów. Władza - konflikty - kultura, 751-987, Warszawa 2011. 
McKITTERICK R., Script and book production, in: Carolingian Culture: emulation and innovation, ed. R. MCKITTERICK, Cambridge 1994, pp. 221-247.

MIŚKIEWICZ M., Zarys kultury $i$ archeologii Europy $w$ okresie wczesnego średniowiecza, Warszawa 2002, p. 186.

RATAJCZAK K., Poglady Ojców Kościoła na wychowanie i edukację kobiet, "Biuletyn Historii Wychowania" 15-16 (2002), pp. 15-23.

RATAJCZAK K., Szkoła pałacowa, [in:] Encyklopedia pedagogiki XXI w., vol. VI, Warszawa 2007, pp. 369-370.

RATAJCZAK K., Sztuki wyzwolone, [in:] Encyklopedia pedagogiczna XXI wieku, vol. VI, Warszawa 2007, pp. 342-343.

RICHÉ P., Chrześcijaństwo na karolińskim Zachodzie (połowa VIII-koniec IX wieku), [in:] Historia chrześcijaństwa. Religia, kultura, polityka, ed. J.M. MEYER et al., vol. 4: Biskupi, mnisi i cesarze. 610-1054, ed. G. DAGRON, P. RICHÉ, A. VAUCHEZ, Warszawa 1999.

SEREJSKI M.H., Karol Wielki na tle swoich czasów, Warszawa 1959.

SKUBISZEWSKI P., Malarstwo europejskie w średniowieczu, vol. 1: Malarstwo karolińskie i przedromańskie, Warszawa 1973.

STĘPNIEWSKA A., Wychowanie rodzinne dziewczą w pedagogice św. Hieronima, "Vox Patrum" 8-9 (1985).

The Gentle Voices of Teachers. Aspects of Learning in the Carolingian Age, ed. R.E. SULLIVAN, Columbus 1995.

WAllaCH L., Charlemagne's De litteris colendis and Alcuin. A diplomatic - historical study, "Speculum" 26 (1951), No. 2, pp. 288-305.

WIES E.W., Karol Wielki. Cesarz i święty, Warszawa 1996.

WOOD I., Kultura, in: Zarys historii Europy, vol. 2: Wczesne średniowiecze od 400 do 1000 r., ed. R. Mc KITTERICK, Warszawa 2003. 